\title{
CURRENT STATUS, CHALLENGES, MANAGEMENT AND FUTURE PERSPECTIVES OF THE RED PALM WEEVIL Rhynchophorus ferrugineus OLIVIER (COLEOPTERA, CURCULIONIDAE) ERADICATION - A REVIEW
}

\author{
Firas Al-Zyoud ${ }^{1, *}$, Rida Shibli ${ }^{2}$, Ihab Ghabeish ${ }^{3}$ \\ ${ }^{1}$ Department of Plant Protection and IPM, Faculty of Agriculture, Mutah University, Karak, 61710 Jordan. \\ ${ }^{2}$ Department of Agricultural Biotechnology and Genetic Engineering, Faculty of Agriculture Technology, Al-Ahliyya Amman University, Amman, Jordan. \\ ${ }^{3}$ Department of Agricultural Sciences, As-Shoubak University College, Al-Balqa' Applied University, Al-Salt 19117, Jordan. \\ Received - October 27, 2021; Revision - December 11, 2021; Accepted - December 25, 2021 \\ Available Online - December 30, 2021
}

DOI: http://dx.doi.org/10.18006/2021.9(6).697.714

\section{KEYWORDS \\ Date palm \\ Red palm weevil \\ Rhynchophorus ferrugineus \\ Integrated pest management \\ Agriculture innovations \\ Sustainability}

\begin{abstract}
The date palm is a cultural and economic heritage of many nations. The red palm weevil, Rhynchophorus ferrugineus Olivier (Coleoptera, Curculionidae) is among the world's most serious insect pests of palms that have rapidly expanded its geographical distribution and host plant range during the last decades. Integrated pest management (IPM) is followed to suppress the pest using the most economical and least hazardous methods to humans and the environment. Since $R$. ferrugineus is a serious pest of date palm production worldwide, farmers, researchers, and scientists have developed many tactics to eradicate this pest. However, there was no published article covering and integrating the current status, biology, ecology, and future control tactics of $R$. ferrugineus and proposes an IPM program. Therefore, in this review, $R$. ferrugineus geographical distribution, host plant range, economic importance, infestation symptoms, morphology, biology, and its management tactics were thoroughly discussed. These tactics include early detection of $R$. ferrugineus infestation, trapping, chemical applications, use of bio-agents, bioinsecticides (plant extracts), resistance cultivars, cultural practices, sterile insect technique, gene silencing technology, quarantine, and geographical information system. In conclusion, all available control tactics suggest that $R$. ferrugineus could be successfully managed by developing IPM programs comprising several means of control. It is hoped that this review will highlight some aspects of date palm management and raise research gaps and directions deserving further investigations to develop a better understanding of $R$. ferrugineus management and therefore contributes to the sustainability of date palm cultivation worldwide.
\end{abstract}

* Corresponding author

E-mail: firaszud@mutah.edu.jo

Peer review under responsibility of Journal of Experimental Biology and Agricultural Sciences.

Production and Hosting by Horizon Publisher India [HPI] (http://www.horizonpublisherindia.in/).

All rights reserved.
All the articles published by Journal of Experimental Biology and Agricultural Sciences are licensed under a Creative Commons Attribution-NonCommercial 4.0 International License Based on a work at www.jebas.org.

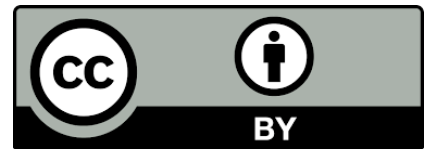




\section{Introduction}

Nowadays the main challenge of the world is to increase agricultural production sustainably. Invasive pest pressures, misuse of a pesticide, scarcity of water, biodiversity losses, land degradation, decreased ecosystem services, desertification, and climate changes are some serious consequences in agricultural production, along with food security and life on the earth (AlZyoud, 2014c; Al-Dosary et al., 2016). Date palm, Phoenix dactylifera L. (Arecales: Arecaceae) is considered the cultural heritage of many nations worldwide. $P$. dactylifera is the oldest known fruit crop, and has been cultivated in the Middle East and North Africa (MENA) since 5,000 years ago (Tenghberg, 2012). $P$. dactylifera is most likely originated in Western India or Southern Iraq (Chao \& Krueger, 2007). Hereafter, the cultivation of date palm spread throughout the Arabian Peninsula and MENA region. Globally, there are 100 million trees of date palm (Jonoobi et al., 2019), covering an area of 1.1 million hectares with a total production of 8.5 MT (FAOSTAT, 2018). Dates are utilized as fruits or in beverages, and their leaves are harvested for fiber. In addition, dates have several medicinal qualities such as antifungal, antibacterial, antiulcer, and antitumor (El-Hadrami \& Al-Khayri, 2012).

The increase in the area under date palm cultivation offers an ideal ecological place for pests to manifest. P. dactylifera is subjected to damage by 112 insects and mite species in 42 families (El-Shafie, 2012). The red palm weevil, Rhynchophorus ferrugineus Olivier (Coleoptera, Curculionidae) is the most common of these pest species (Abd El-Fattaha et al., 2021). R. ferrugineus was firstly reported in the Middle East in the UAE in 1985, from where it was spreading to other countries worldwide, mainly via infested plant materials (Al-Shawaf et al., 2013; Kurdi et al., 2021). $R$. ferrugineus is a serious insect pest of palms in many agroecosystems worldwide (Faleiro et al., 2014, 2019). The pest has expanded its geographical distribution and host plant range during the last three decades (Giblin-Davis et al., 2013). It has been recorded to infest 40 species of palms, in which date palm, coconut palm, and canary palm are the most susceptible ones (Mohammed et al., 2020). R. ferrugineus is considered as a hidden borer of palms, thus it is extremely difficult to detect its infestation early. The infestation mostly occurs at the trunk base near the soil (Sallam et al., 2012), making detection extremely challenging and difficult (Dembilio \& Jacas, 2012). Larvae live inside the tree trunk, damage the vascular system and dig deeply in the host, leading to date palm tree collapse, if not treated, the palm could die during a period of six to eight months (Ju et al., 2011).

The cryptic lifestyle of $R$. ferrugineus larvae in the trunk exhibits management difficulties and challenges (Hussain et al., 2019). Its control depends mainly on the intensive use of synthetic insecticides such as emamectin benzoate (Chihaoui-Meridja et al., 2020), chlorpyrifos, fipronil, and methomyl (El-Gohary et al., 2015), imidacloprid (Abd El-Fattahaet al., 2021), applied as tree' trunk injection or fumigation, soil treatment, the crown drenching of infested trees and wound dressing (Hussain et al., 2013). However, synthetic insecticides have exerted many side effects on human health and the environment, and the weevil has developed resistance against many insecticides (Wakil et al., 2018). Sustainable agriculture is essential to the future of human beings (Shojaei et al., 2013), and aims to achieve adequate safe food production, and improve the livelihoods of growers (Uwagboe et al., 2012). Integrated pest management (IPM) is used to control pest damage by the most cost-effective means and the least hazards to humans and the environment (Ofuoku et al., 2009). IPM is a decision-based process involving the coordinated use of many tactics for optimizing pest control in an economically and environmentally sound manner (Al-Zyoud, 2013, 2014a, b, 2015). However, large areas under agricultural production are facing unacceptable losses due to pests or suffering from intense use of pesticides worldwide, which led scientists to suggest that new paradigms are required (Kogan, 1998).

\section{Objectives and scope of the study}

Understanding of pest life history and habits is the foundation of effective pest management tactics. Furthermore, date palm producers have numerous difficulties and hurdles in eradicating $R$. ferrugineus; there is no systematic IPM program in place, failure to detect infestations early, insufficient quarantine measures, and a lack of farmer training on $R$. ferrugineus management. Although many efforts have been made to develop IPM strategies during the previous years, it is still unable to successfully control $R$. ferrugineus in an environmentally sound manner. In addition, successful pest managers learned that incorporating several effective control tactics into an IPM strategy is the most acceptable and effective way to manage pests over the long term. Thus, coherently addressing the $R$. ferrugineus problem at a global level is urgently needed to efficiently manage the pest on a sustainable basis. However, no information was available on the integrated work to comprehensively cover the current management strategies, challenges, and future perspectives of $R$. ferrugineus eradication despite the outbreaks experienced over the last three decades worldwide. Therefore, this article aims at providing a better understanding of the current status of the pest, biological and ecological parameters, and future control options of $R$. ferrugineus. An overview of $R$. ferrugineus control strategies used to manage $R$. ferrugineus in palm cultivation is presented in this review article. This review article focused on the geographical distribution, host plants, economic damage, infestation symptoms, morphology, and biology of $R$. ferrugineus. In addition, this review also provides a discussion on the pest surveillance for early detection of 
infestation, trapping, chemical applications, bio-agents, plant extracts, host plant resistance, cultural practices, sterile insect technique (SIT), gene silencing technology, quarantine, and geographical information system (GIS), and to recommend an efficient IPM program to eradicate $R$. ferrugineus worldwide. It is hoped that this review will highlight some aspects of $R$. ferrugineus and raise research gaps and directions deserving further development to create a better understanding of $R$. ferrugineus management through sustainable IPM programs.

\section{The red palm weevil $R$. ferrugineus}

\subsection{Geographical distribution and host range}

The red palm weevil is the most destructive pest of date palms worldwide (Faleiro et al., 2014; Ferry, 2019; Sabit et al., 2021). The pest has expanded its geographical distribution and host range during the last three decades and threatened worldwide date palm trees (Giblin-Davis et al., 2013). FAO has been considered $R$. ferrugineus as a category- 1 pest on date palm in the Middle East (FAO, 2017). R. ferrugineus has a significant socio-economic influence on the date palm production sector in the pest-infested countries, especially in the MENA region, in which this region accounts for $90 \%$ of the global date production. The geographic origin of R. ferrugineus was claimed to be South East Asia (Sabit et al., 2021) and it was first reported as a pest on the Indian coconut palm in 1906 (Lefroy, 1906), and then on date palm in 1917 (Brand, 1917). In the Middle East countries, R. ferrugineus was first detected in the UAE during 1985, hereafter the pest spread through infested plant materials to other data-producing countries in the region (Faleiro et al., 2012; Al-Shawaf et al., 2013). Thereafter, the pest was reported in the KSA in 1987 , Jordan in 1994, Palestine in 1999, Italy in 2004, the Canary Islands in 2005, France and Greece in 2006, and Turkey in 2007 (Kehat, 1999; Kontodimas et al., 2006). However, R. ferrugineus has gained a foothold on palms in the Middle East, and then expanded its geographical distribution to many Asian, European, African, American, and Australian countries (Giblin-Davis et al., 2013; Wahizatul et al., 2013). Recently, the pest is reported in 46 palms growing countries and attacking 40 palm species of which date palm, coconut palm, and canary date palm are the most infested ones (Giblin-Davis et al., 2013; Faleiro et al., 2014). It has a long host plants list including nigbong palm, yeara palm, ornamental palm, oil palm, royal palm, sedang palm, sago palm, talipot palm, sugar palm, and many other species, i.e. Borassus flabellifer, Arenga pinnata, Areca catechu, Oreodoxa regia, Caryota urensi, Caryota cumingii, Caryota maxima, Corypha elata, Cocos nucifera, Livistona decipiens, Elaeis guineensis, Metroxylon sagu, Phoenix canariensis, Phoenix sylvestris, Phoenix dactylifera, Phoenix theophrasti, Trachycarpus fortune, Sabal umbraculifera, and Washingtonia spp.

\subsection{Economic importance and infestation symptoms}

Direct losses due to the $R$. ferrugineus attack can be attributed to the value of damaged palms, loss in date yield, and cost of implementation of the management program. Each year, the removal of badly afflicted trees alone costs the Gulf countries and the Middle East is of USD 8 million. Pest treatment, removal, and replacement of infested palms and loss of benefits cost over $€ 90$ million in Italy, Spain, and France by 2013. If a strict containment program is not implemented, the cost is expected to rise to $€ 200$ million by 2023 (FAO, 2017). The estimated costs of curative control of date palms in the early stage of infestation are \$US 103.7 million at a 5\% infestation level (Sarwar, 2016). Indirect losses may result from the restriction of trees' movement, curtailing the expansion of new plantations, adversely affecting the environment and landscape due to the massive use of chemicals.

Early symptoms are difficult to detect (Mahmud et al., 2015) because $R$. ferrugineus spends its immature stages inside the tree trunk, and the final stages of its life cycle are only detected when the palm tree is no longer viable (Chong, 2015), and mostly infest young trees less than 20 years old (Faleiro, 2006). The infestation differs according to the age and height of the tree. With respect to the height of palms, Khalifa et al. (2007) suggested that $78 \%$ of the pest infestation occurs at $0-50 \mathrm{~cm}$ and only $20 \%$ at $51-100 \mathrm{~cm}$, in which $98 \%$ of the infestation occur below $1 \mathrm{~m}$ height. However, above $3 \mathrm{~m}$, the infestation could be rarely detected. Further, concerning tree age, $13 \%$ infestation level was found at ages up to 5-year-old and $65 \%$ at 6-10years of age, and there is a negative correlation between the infestation percentage and the age of the tree up to 20-year-old (Faleiro, 2006). This might be due to the fact that infestation occurs at the crown base of the tree, and then the pest larvae move downward until the tree collapsed at that height.

The red palm weevil may exhibit the following symptoms of infestation; oozing of brownish fluid, larval tunnels inside the tree tissues, drying of outer leaves, fruit bunches and infested offshoots, presence of the pest stages at the frond base or near the infested palm trees, and the toppling of the trunk in case of heavy damage (Faleiro et al., 2012). The infestation of $R$. ferrugineus can also cause yellowing and wilting of trees that leading to the death of the trees. The crown wilts first, and then will follow by the lower leaves due to damage to the tree vascular tissues (Pereira, 2017). At higher pest infestation, sounds of larval chewing can be heard by placing one's ear to the tree trunk (Martin, 2015). Secondary infections of bacterial and fungal pathogens may occur within the damaged tissues, which resulted in the accelerating the damage. As time progresses, the external symptoms are observed, and damage is enough to kill the palm tree, and the infestation may have been presented for at least 6 months. 


\subsection{Biology and morphology}

The pest completes its development within the palm trunk and passes through 4 life stages; eggs, larvae, pupae, and adults. After mating, which characteristically involves multiple inseminations to assure fertility, the females disperse in searching for oviposition sites (Dembilio \& Jacas, 2011). Volatiles emitted from fresh palm wounds attract gravid females for egg-laying (Salama \& Abdel-Razek, 2002). To lay eggs, the females use their long rostrum to bore a hole into tree tissues. Each female lays 250-500 creamy white, glossy, oval shaped eggs (1-2.5 mm) in wounds, crevices, and cracks in the tree trunk, and deposited eggs hatch in 2-6 days (Salama \& Abdel-Razek, 2002). The newly emerged larvae are yellow-white in color and legless, with a chitinous head capsule, which is dark-brown than the rest of the body. Larvae burrow from leaf axils to crown using strong horizontal conical jaws, where they feed on tree tissues and bore their way into the tree center. The larval development duration depends upon host nutrition, temperature, and humidity, and it passes through 13 larval instars (Giblin-Davis et al., 2013). Larvae are curculioni form, and the last larval stage is $5 \mathrm{~cm}$ long $\times 2 \mathrm{~cm}$ wide. Larvae feed on the tree's internal tissues by digging deep galleries in the palm. Hereafter, the galleries are filled with debris mixed with the plant ferment. This fermentation process produces heat up to $40^{\circ} \mathrm{C}$, which is favorable to the larval development whatever the outside temperature. After completing its development, the larva forms a cocoon $(3.5 \mathrm{~cm}$ long $\times 1.5 \mathrm{~cm}$ wide). The pupal stage lasts 15 30 days after which a reddish-brown adult $(4.0 \mathrm{~cm}$ long $\times 1.2 \mathrm{~cm}$ wide) emerges and can live for 3 months (Hallett et al., 2004; AlDosary et al., 2016). There are two colors for $R$. ferrugineus predominantly reddish-brown or dark with red streaks. Adult males are characterized by a tuff of bristles on the dorsal tip of the rostrum (Al-Dosary et al., 2016).

Being a destructive pest, $R$. ferrugineus can reproduce and spread very fast as it only needs a short period of 3-4 months to finish its life cycle (Hussain et al., 2013). Oviposition in R. ferrugineus is strongly affected by temperature with 1-2 generations/year. Within a single afflicted palm, multiple generations of $R$. ferrugineus may coexist (Dembilio \& Jacas, 2012). In the Middle East, adults are most active during March to May, and once again in October and November (Soroker et al., 2005). In nature, R. ferrugineus population is highly aggregated since the infestations often occur in clusters (Massoud et al., 2012). The adults are powerful fliers, flying up to $900 \mathrm{~m}$ at a time, and they can move up to $7 \mathrm{~km}$ within a week (Abbas et al., 2006). Flight mill studies indicated that adults could potentially fly a distance of $50 \mathrm{~km}$ with flight activity being predominantly diurnal (Hoddle et al., 2015).

\section{Pest management}

A constant battle for higher crop yields is needed to meet the increasing global food demands worldwide. Agricultural pests destroy important food reserves in every part of the world (Kring, 1998). The main method of pest control adopted by the majority of farmers is abusive of pesticides (Al-Zyoud, 2013, 2014a,b,c, 2015; Chihaoui-Meridja et al., 2020). Pesticides helped the world meets the increasing food demand by enhancing agriculture production through controlling pests, however, the misuse of pesticides in agriculture caused their widespread diffusion to all environmental compartments (Morohashi et al., 2012; Al-Zyoud, 2014c). IPM approach has been applied in many $R$. ferrugineus-infested countries (Gomez et al., 2009; Al-Dosary et al., 2016, Ferry, 2019). Several control tactics have been established and/or are currently being in use to tackle threats in date palm plantations, i.e. pest surveillance, trapping, chemical control, limited use of bioagents, bioinsecticides, host plant resistance, cultural practices, sterile insect technique (SIT), gene silencing technology, quarantine, and GIS (Vacas et al., 2017; Wakil et al., 2017; Musmeci et al., 2018; Al-Dawsari, 2019; Malik et al., 2019; Chihaoui-Meridja et al., 2020; Sabit et al., 2021). However, an effective $R$. ferrugineus-IPM strategy is still awaited.

\subsection{Early detection and surveillance}

Unfortunately, visible symptoms of $R$. ferrugineus infestation appear at a later stage after severe damage of plant tissues, where it is late to save the tree (Chong, 2015; Mahmud et al., 2015). Thus, delay in detection of infestation is the main obstacle in $R$. ferrugineus control. Before implementing the IPM strategy, surveillance is essential to ascertain the presence of $R$. ferrugineus. Developing a reliable method that can detect the infestation at an early stage is needed for effective control. However, several detection tactics such as visual inspection, pheromone traps, thermal detection and spectral imaging, chemical detection, and acoustic detection have been tested to determine the infestation at early stages (Potamitis et al., 2009; Mankin et al., 2011; Kurdi et al., 2021). The current state of knowledge indicates that, although no single method perfectly detects the infestation, a combination of detection methods can provide almost $100 \%$ success. A worthy detection method should be fast, accurate, non-destructive, and at an affordable cost.

\subsubsection{Visual inspection}

The most obvious approach to detect pest infestation is the visual examination of the crown, stem, offshoots, and base of palm trees (Mankin et al., 2011). These can be holes on trunk and bases of frond petiole, oozing, frass composed of chewed tree tissue with fermenting odor, adults and their pupal cocoons near the tree, dry offshoots, and breaking of trunk/crown (El-Shafie \& Faleiro, 2020). Monthly monitoring of highly infested trees could effectively maintain the infestation at less than $1 \%$ level (AlShawaf et al., 2012) because the infestation is detected before adults' emergence, which takes 1.5 months from egg to adult 
emergence. Nevertheless, the visual monitoring of date palms to determine the infestation is time consuming and laborious, but in combination with pheromone traps; it forms a main aid component of IPM.

\subsubsection{Pheromone traps}

Monitoring pheromone traps are a common tool in sustainable IPM programs on a wide scale as an alternative to hazardous insecticides. Due to the synthesis of $R$. ferrugineus male produced aggregation pheromone (ferrugineol, 4-methyl-5-nonanol) (Hallett et al., 1993), pheromone traps are broadly used in mass trapping of the pest in the infested countries (Faleiro, 2006; Oehlschlager, 2016). R. ferrugineus is attracted to the aggregation pheromone which adult males released to attract both sexes to host trees that are suitable for larval feeding. Neither the stressed-palm odor nor the adult aggregation pheromone is very effective in pest attracting on their own, but the combination of both can be effective in attracting adults to traps (Soroker et al., 2017; Vacas et al., 2017). For better results, the pheromone traps should be regularly examined for trapped adult collection, trap cleaning, renew of food bait and, replacement of exhausted pheromones. Although $R$. ferrugineus pheromone trap captures females, only a part of the pest population is captured by pheromone traps, and therefore trapping should be combined with other IPM tactics.

\subsubsection{Thermal detection and spectral imaging}

Conventional visual detection of infestation is not only laborious and costly but also inaccurate; especially in cases where the damage occurs below the crown. This situation calls for large scale-area wide detection methods; however, another alternative approach is using thermal imaging to monitor physiological changes that occur in palm trees. Two approaches have been evaluated: (1) monitoring local increase in stem temperature (4$26^{\circ} \mathrm{C}$ above the ambient level) caused by intensive fermentation of plant tissues following larval feeding activity (El-Faki et al., 2016; Soroker et al., 2017), and (2) water stress in palms is being monitored due to damage to the tree's vascular system caused by larval digging through the stem tissues (Cohen et al., 2012). Temperature elevation can be monitored by probes inserted into the palm stem (El-Faki et al., 2016). On the other hand, the change in crop-water status that reflects the decrease in stomatal conductance causes an increase in canopy temperature that can be detected by inspecting the thermal portion of the spectrum of the reflected irradiation before any visible symptoms were detected (Golomb et al., 2015). Aerial photography can be used to obtain remote thermal canopy imaging. These technological advancements allow for the acquisition of spatial data, allowing for the mapping of palm canopy temperature across a large region in a single aerial imaging session (Golomb et al., 2015). Infrared cameras were also used to detect a rise in temperature in infested palms.

\subsubsection{Chemical detection}

The potential of the chemical method of pest inspection is based on the assumption that infested palm trees emit characteristic volatile materials. These volatiles may be derived from $R$. ferrugineus itself, its frass, or infested palm wounds. Thick brown repulsively-smelling oozing liquids are often associated with $R$. ferrugineus infested palms (Vacas et al., 2014). It is stated that the amount of volatiles produced by palm tree is very low but some changes in volatile emission can be noticed as the pest infestation progress. Thus, it is likely that chemical detection can be done using targeted olfactory sensors, i.e. electronic nose/tongue (Littardi et al., 2013). However, the chemical detection tactic for $R$. ferrugineus infested trees has been successfully implemented using sniffing dogs. Golden Retriever, labrador, and german shepherd dogs have successfully sniffed and detected the oozing secretion produced by $R$. ferrugineus infested palm trees (Suma et al., 2014). After training, dogs were $70-80 \%$ accurate in detecting the infested trees even when palms were infested with only one larva (Suma et al., 2014; Soroker et al., 2017). Still few pitfalls require consideration; a dog implementation requires professional and trained personal.

\subsubsection{Acoustic detection}

Acoustic technology has been used for the detection of hidden infestation (Mankin et al., 2016). Several acoustic detection systems have been successfully used to detect $R$. ferrugineus larval sounds under laboratory and field conditions (Rach et al., 2013; Mankin et al., 2016). Automated systems have been developed to identify spectral and temporal patterns in larval feeding and movement activities which help distinguish the larval sounds from background noise (Mankin et al., 2008; Hetzroni et al., 2016). Introducing microcontroller platforms such as Arduino Uno and Atmel SAMG55 has enabled the development of low-cost detection systems that provide onboard signal processing and memory storage (Mankin et al., 2016). Because many of the current field studies make use of Global Positioning System (GPS) coordinates for mapping of infestations (Mankin et al., 2016), the new devices could be made more user-friendly by including GPS features in the software. Potamitis \& Rigakis (2015) reported an automated pheromone E-trap that uses optoelectronic sensors connected to a microcontroller platform to sense when the pest falls into the pheromone trap and then transmits time of detection to a cell phone or network interface linked through a global system for mobile communication protocols. Psirofonia et al. (2017) reported the use of unmanned aerial vehicles to identify visible signs of infestation in palm plantations. 


\subsection{Trapping}

\subsubsection{Lure and kill (semiochemicals)}

The 'lure and kill' technology has been used to control insect pests in a wide range of crops worldwide (El-Shafie et al., 2011). 'Lure and kill' products formulated as a paste using ferrugineol and cypermethrin have been evaluated on a large scale to control $R$. ferrugineus in infested date palm in the KSA and oil palm in India (Faleiro et al., 2016). The card system of Smart Ferrolure ${ }^{\mathrm{TM}}$ combines the pheromone lure (ferrolure + ethyl acetate) attached to a card laced with cypermethrin (El-Shafie et al., 2011). Providing the traps with non-repellent and odorless insecticides will prevent escaping the captured adults (Faleiro, 2006). A 3-month field trial in date palms in the KSA to control R. ferrugineus showed that the trapping efficiency of the bait-free method (Ferrugineol @ 15\% and the insecticide cypermethrin @ 5\% are combined in an amorphous and flowable paste to create a food bait-free 'attract and kill' formulation) is comparable to the food baited-pheromone traps (El-Shafie et al., 2011).

\subsubsection{Attract and infect}

This strategy could assist in augmenting biological control efforts against $R$. ferrugineus using the entomopathogenic fungi (EPF) set in the pheromone traps. The trap should restrain $R$. ferrugineus adults long enough to be infected by the fungus, and also allow adults to leave the traps in enough healthy conditions so that the adults have the chance to find a mate and transfer the fungus (Soroker et al., 2015). Hajjar et al. (2015) reported the possibility of infecting $R$. ferrugineus adults with the fungus, Beauveria bassiana solid formulation using pheromone traps under laboratory and semi-field caged conditions.

\subsubsection{Dry traps}

Soroker et al. (2015) determined several $R$. ferrugineus host attractants (ethyl propionate, ethyl alcohol, ethyl acetate, gammanonanoic lactone, and pentan-1-ol, 2-methoxy-4-vinyl phenol). Once these attractants are used as food baits in the pheromone traps they increase adult captures several folds. These attractants are potential $R$. ferrugineus pheromone lures and could eliminate the need for frequent food bait replacement in the trap. The Electra Trap TM is a dry trap of dome shape with the pheromone and a coattractant (ethyl acetate). This trap does not need any servicing for at least 4 months, and its trapping efficiency is similar to the traditional food baited trap where the food bait has to be renewed at least bi-weekly (El-Shafie et al., 2011). However, developing smart dry traps would ensure automatic data collection and transmission that would be useful in decision making of an areawide control program.

\subsubsection{Trap components}

A wide range of $R$. ferrugineus pheromone (ferrugineol) lures are available commercially. A related ketone (ferrugineone) increased adult capturing by $65 \%$ (Abraham et al., 1998). Ideally, a lure should last long in the field and $R$. ferrugineus pheromone lures have been reported to have 3-month field longevity when traps are placed under the shade (Hallett et al., 1999). Combining the pheromone with food odor significantly increases the pest attraction (Faleiro, 2006). Fermenting food baits is important for enhancing and sustaining the efficiency of $R$. ferrugineus pheromone traps (Oehlschlager, 2016). In an area-wide operation where mass trapping is practiced, it would be advisable to use food bait that is not only efficient but also readily available and not costly. The odorless insecticide is added to the food bait and water to kill the trapped adults and prevent their escapes, while insecticide-free funnel traps have been reported to be effective in retaining captured adults (Hallett et al., 1999). Ethyl acetate is a known co-attractant (kairomone) when incorporated in food-baited pheromone traps increases adult captures by 2-5 folds compared to ferrugineol alone (Oehlschlager, 2016; Vacas et al., 2017). The most attractive traps at present are those containing fermenting food and emitting both pheromone and ethyl acetate. Pheromone is usually emitted at $3-10 \mathrm{mg} / \mathrm{day}$, food is added at a rate of 150-350 $\mathrm{g} /$ day and ethyl acetate is evaporated at a rate of $200-400 \mathrm{mg} /$ day (Oehlschlager, 2016).

\subsubsection{Trap's design, color, placement and density}

Traps' efficacy is not only depending on the lure, but it also depends on several other factors such as trap' design, color, placement, and density. With regard to trapping design, 4-window bucket traps are the most widespread model used to capture $R$. ferrugineus due to their operational ease in servicing and trapping efficiency (Vacas et al., 2013). Dome-shaped traps (Picusan) capture more adults as compared to bucket traps (Vacas et al., 2013). Both bucket and Picusan traps should be serviced at fortnightly intervals when the food bait and water are renewed. A rough-outer trap surface is recommended to facilitate the entry of arriving adults into the trap. Placing pheromone traps on the ground away from young trees in the susceptible age group $(<20$ years old) offers a landing surface for the attracted adults, which later move into the traps. Pheromone traps may be hung on trunks of mature trees at 1-meter palm stumps hollowed in the center. Dark colored traps (black, red, or reddish-brown) capture significantly more adults than white colored ones (Zohary \& Hopf, 2000; Abuagla \& Al-Deeb, 2012; Al-Saoud, 2013). Trap spatial distribution is another important issue to be considered. Trap density in mass trapping programs would be governed by the extent of human resources available for trap servicing and also by the adult activity in the field. In case of persistent adult captures in monitoring traps or the infestation is detected, mass trapping could 
be initiated at 1-4 traps/ha, however, in palm trees with high adul activity 4-10 traps/ha are efficiently captured the newly emerging adults (Soroker et al., 2005; Faleiro et al., 2011).

\subsection{Chemical control}

Pesticides are very important for the world to meet the increasing food demand by improving agriculture production through managing agricultural pests (Al-Zyoud, 2014a,b,c). Synthetic insecticides are the most common control method used against $R$. ferrugineus and can apply in several ways. The most commonly used insecticides are chlorpyrifos, fipronil, and methomyl (ElGohary et al., 2015), emamectin benzoate (Chihaoui-Meridja et al., 2020), imidacloprid (Abd El-Fattaha et al., 2021), and carbaryl (Hernandez-Marante et al., 2003). Insecticidal applications protect fresh injuries from adult' female infestation and prevent egg-laying (Abraham et al., 1998). Nowadays, preventive and curative insecticides apply to control the pest. The preventive treatments are repeated every 3 months especially during $R$. ferrugineus peak activity periods of the year (April to June and September to November). Curative treatments are applied as a spray (shower) or stem injection. Curative insecticide applications of trees at early infestation through stem injection methods are known to save the trees. The stem injection method has been widely used against $R$. ferrugineus (Ferry \& Gomez, 2014a, 2015; Dembilio et al., 2015). For stem injection, points should be marked around the tree trunk, either in spiral manners or at the trunk' base, and these are depending on insecticide use and infestation pattern. Treatments by injection are based on introducing an insecticide in the palm through holes in the stipe realized by drilling or by percussion. This technique leads to the creation of wounds (Dembilio et al., 2015). Various factors contribute to increasing wound size such as high pressure and type of insecticide or dilution (Ferry \& Gomez, 2015). In the case of pressure injection, the pressure should not exceed than 1 bar to avoid tissue damage when the chemicals are forced into the tree at high pressure (Al-Shawaf et al., 2012). The holes' size and number must be as small as possible but must be sufficient to obtain a good insecticidal dispersion. If all offshoots have been removed, the treatment is easier to apply (Ferry \& Gomez, 2015). Long persistency synthetic insecticides have great benefits by decreasing the number of injections and interventions. In urban areas, the use of such techniques is more practical and safe for both humans and the environment than soaking the trees (Ferry \& Gomez, 2014b). Drilling three small holes, each $1 \mathrm{~cm}$ in diameter and 10-15 cm in-depth, and filling them with a simple and low-cost device is all that is required for an injectable treatment (dosing gun or funnel). Chemical treatment is based on two different conceptions on the way to reach and kill the larvae by direct contact of the insecticide through reaching the galleries made by the larvae. This technique can be efficient but it requires high pressure obtained with pumps. High pressure will make part of living tissues cells explode and create stipe mechanical weakness that could generate a palm failure risk in the future. Treatments with synthetic systemic insecticides injected in the soil or diluted in the irrigation water have been used with positive results (Kaakeh, 2006; Dembilio et al., 2010a). In injection techniques, it is very important to take into consideration not only the active ingredient but also the formulation of the insecticide (Ferry \& Gomez, 2014a).

Initially, organophosphates and carbamates were used in both preventive and curative applications (Faleiro, 2006). However, a new insecticidal generation (neonicotinoid and phenylpyrazole) is used to suppress the pest infestation (Kaakeh, 2006; Al-Shawaf et al., 2010). However, there is a lack of protocols for carrying out preventive and curative treatments commonly used to control $R$. ferrugineus (Ferry \& Gomez, 2014a; Dembilio et al., 2015). Regular preventive insecticide applications could often be excessive and unnecessary. Intensifying periodic inspection to detect infestation instead of periodic sprays could help successfully control $R$. ferrugineus. A new injectable technique, microinfusion of an avermectin pesticide, allows palm trees to be protected simply and affordably for a year. The most important issue in insecticidal treatments is how to reach $R$. ferrugineus in its different forms rather than the insecticide kind to apply (Ferry \& Gomez, 2012). It is known that the pest adults hide deeply at the base of the frond petioles. To reach this location, the traditional insecticide sprays are not effective (Vidyasagar et al., 2000), although it is still frequent to check such mode of treatments applied. For treatment effectiveness against the pest adults in palms of <2-3 meter stipe height, the offshoots, frond, and petioles bases must be soaked, while for tall palms, the base of central and medium crown leaves must be soaked.

One of the first concerns in the use of insecticides for productive date palms is the insecticide residues in the dates (Al-Samarrie \& Akela, 2011; Abd-Rabou et al., 2015). According to El-Saeid \& Al-Dosari (2010), chlorpyrifos residual is detected in Riyadh dates in the KSA market. Frequent insecticide treatments are unsustainable and create a health risk for the workers and for oasis inhabitants. The effectiveness of insecticide treatments is very often assessed without taking into consideration that these treatments have to be considered imperatively as one of the components of an IPM program (Al-Dosary et al., 2016).

\subsection{Biological control}

There is a growing body of interest in finding control methods for pests other than pesticides worldwide (Al-Zyoud, 2015), due to the development of pesticide resistance (Kranthi et al., 2001), and the successful use of natural enemies against many pest species (AlZyoud, 2013). Biological control is an ecological approach that provides environmentally harmonious, economical pest 
management, and a safe alternative method for pest suppression (Sarwar, 2016). However, biological control of pests by natural enemies represents a major tactic whose potential effectiveness has gone unrealized in many affected cropping systems worldwide (Naranjo \& Ellsworth, 2009). Recently, it has become clear that new control methods in the agricultural industry are required (Hosseini et al., 2010), and it has become increasingly important to policy-makers and the agricultural industry (Marsh \& Gallardo, 2009). Various natural enemies including the entomopathogenic microorganisms (fungi, nematodes, bacteria, viruses, and protozoa), and predators, and parasitoids have been reported to attack $R$. ferrugineus.

\subsubsection{Entomopathogenic fungi (EPF)}

Some species of the EPF affect the existence and multiplication of $R$. ferrugineus. B. bassiana is a promising bio-agent candidate against $R$. ferrugineus (Hussain et al., 2015; Jalinas et al., 2015). $B$. bassiana infects all developmental stages of the red palm weevil (Llacer et al., 2013), reduces fecundity and egg hatching (Dembilio et al., 2010b), and causes high adult mortality under field conditions (Guerri-Agullo et al., 2011). Sewify et al. (2009) showed a considerable reduction of $R$. ferrugineus populations after applying B. bassiana. The fungi, Metarhizium anisopliae, and $M$. pingshaense have revealed good pathogenicity against $R$. ferrugineus (Francardi et al., 2013; Cito et al., 2014). A novel method of microencapsulation technology has been developed to increase the shelf life and tolerance to UV light of B. bassiana, and such technology needs to be explored in the future for incorporation in IPM strategies. These results confirm that the fungi are noteworthy to be used in $R$. ferrugineus IPM programs (Mazza et al., 2014).

\subsubsection{Entomopathogenic nematodes (EPNs)}

The entomopathogenic nematodes (EPNs), Teratorhabditis synpapillata Sudhaus, and Praecocilenchus ferruginophorus Rao \& Reddy are parasitized $R$. ferrugineus adults (Kanzaki et al., 2008). Heterorhabditis indicus Poinar has a great control potential against $R$. ferrugineus with $100 \%$ larvae and adult mortality in the laboratory and $67 \%$ larval mortality in the field (Abbas et al., 2001; Elawad et al., 2007). The EPNs, Steinernema carpocapsae Weiser and $H$. bacteriophora infect different stages of $R$. ferrugineus (Mastore et al., 2015; Santhi et al., 2015). The EPNs, $S$. affine, S. feltiae, and H. bacteriophora cause mortality to $R$. ferrugineus larvae, with the highest larval mortality caused by $H$. bacteriophora (94\%) (Gozel et al., 2015). In another study, $H$. bacteriophora was reported as the most effective species on $R$. ferrugineus larvae followed by S. longicaudum, S. glaseri, S. carpocapsae, and S. Krausse (Triggiani \& Tarasco, 2011). S. carpocapsae and H. bacteriophora caused $97 \%$ and $86 \%$ mortality of $R$. ferrugineus, respectively (Manzoor et al., 2017). Thus, it could be recommended that EPNs could be used as bio-agents for
$R$. ferrugineus management, and integrated with EPF for successful control of $R$. ferrugineus (Wakil et al., 2017).

\subsubsection{Entomopathogenic bacteria (EPB)}

The entomopathogenic bacteria (EPB), Bacillus thuringiensis (Manachini et al., 2009), B. sphaericus, B. laterosporus, B. megatherium, Pseudomonas aeruginosa (Salama et al., 2004), and Serratia marcescens (Pu \& Hou, 2016) are found to be pathogenic to R. ferrugineus. B. thuringiensis can be used in R. ferrugineus control as a potential bio-agent and it caused $94 \%$ mortality of the $2^{\text {nd }}$ larval instars after 15 days of application ( $\mathrm{Pu}$ et al., 2017). Mahmoud et al. (2011) demonstrated the highest $R$. ferrugineus mortalities of $76 \%, 84 \%$, and $100 \%$ after 24, 48, and 72 hours of $B$. thuringiensis application. B. thuringiensis subsp. kurstaki caused $70 \%$ larval mortality in the laboratory (Manachini et al., 2009). Malik et al. (2019) suggested that the combination use of the fungus, B. bassiana, and the bacterium, B. thuringiensis could be an effective tactic in the red palm weevil control.

\subsubsection{Viruses and protozoa}

The highly potent cytoplasmic polyhedrosis virus infected all developmental stages of $R$. ferrugineus, and laboratory infection of older larvae resulted in malformed adult' development (Gopinadhan et al., 1990). El-Minshawy et al. (2005) found that even when the virus was stored at $-4^{\circ} \mathrm{C}$ for 18 months, there were no significant differences in $\mathrm{LC}_{50}$ between the frozen stored Rhynchophorus-polyhedrosis virus and the newly extracted one against the red palm weevil. In addition, in the digestive tracts of $R$. ferrugineus, there seems to be synergistically degraded by flagellated protozoa (Ragaei et al., 2009).

\subsubsection{Parasitoids and predators}

The scollid wasp, Scolia erratica Smith (Hym., Scoliidae) is considered as an ectoparasitoid of the red palm weevil larvae (Sarwar, 2016), while the sarcophagid fly, Sarcophaga fuscicauda Bottcher attacks adults (Mazza et al., 2014). The parasitoid mites, Tetrapolypus rhynchophori Ewing, Rhynchopolipus swiftae Husband \&O'Connor, and R. rhynchophori (Ewing) have been recorded parasitizing adults (Abdullah, 2009; Al-Deeb et al., 2012). The predatory earwigs, Chelisoches morio (Fabr.), Anisolabis maritime Bonelli and Euborellia annulipes (Lucas), and the anthocorid, Xylocorus galactinus (Fieber) are some of the common predators of the pest (Mazza et al., 2014; Sarwar, 2016). The predatory bug, Platymeris laevicollis Distant preyed upon $R$. ferrugineus (Mazza et al., 2014).

\subsection{Bioinsecticides (Plant extracts)}

The drawbacks of synthetic chemical insecticides in the agriculture sector led to increase the interest in using plant extracts as an 
alternative control method in pest management (Shannag et al., 2015). Using plant extracts to control insect pests could result in declining environmental pollution, eliminating toxicity to humans, and preserving non-target organisms (Sarwar et al., 2013). The active ingredient (Azadirachtin) of the neem tree is the most known promising plant species being used for the synthesis of bioinsecticides (Shannag et al., 2015), and more than 200 insect species were reported to be controlled by extracts derived from the neem tree. Nassar \& Abdullah (2001) reported that Azadirachtin was very toxic against different developmental stages of $R$. ferrugineus. Seed powder of cardamom, Elettaria cardamomum and clove, Syzygium aromaticum resulted in $100 \%$ adult mortality of $R$. ferrugineus after 3 days of application (Al-Dawsari, 2019). Among 13 plant extracts for controlling $R$. ferrugineus, the ethanol extracts of sea ambrosia ( $91 \%$ mortality), French cotton $(86 \%$ mortality) and curcuma ( $85 \%$ mortality) have the highest toxicity against $R$. ferrugineus in laboratory and field experiments (Salama, 2007). Topical application of Jojoba, Boxus chinensis oil resulted in $R$. ferrugenius larval mortality of $99 \%$ and adult mortality of $73 \%$ (Nassar \& Abdullah, 2005). However, to control $R$. ferrugineus, more emphasis should be paid to the insecticidal capabilities of plant secondary metabolites such as rotenone, coumarin, limonine, and piperine (Al-Jabr et al., 2017). Thus, plant extracts could be exploited in developing more effective strategies to control of $R$. ferrugineus.

\subsection{Host plant resistance}

Over millions of years of interaction with herbivores, plants have evolved a broad range of defensive mechanisms to pest attacks (Smith \& Clement, 2012). The use of plant resistant cultivars against pests is desired control method due to their effectiveness, safe to humans and environment, maintenance of natural balances within the ecosystem, and a major component of IPM strategies worldwide (Al-Zyoud et al., 2009, 2015). Host plant resistance is important for the successful management of $R$. ferrugineus in date palms. Date palm cultivars like Mazafati with hard tissues and high calcium contents inhibit the development of red palm weevil (Faleiro, 2006; Al-Ayedh, 2008). However, it was found that the date palm cultivars, Khlas (Faleiro et al., 2014) and Sukkary (AlAyedh, 2008) are highly preferred by $R$. ferrugineus, while the European fan palm and the California fan palm appear to be resistant to the pest (Dembilio et al., 2009). Although host plant resistance mechanisms involving antixenosis and antibiotic effects are known (Dembilio et al., 2009; Faleiro et al., 2014), host plant resistance is not well utilized at the present for $R$. ferrugineus management.

\subsection{Cultural control}

Due to the adverse effects of pesticides (Kranthi et al., 2001), the interest in cultural control methodologies for pest management is renewed, and nowadays they form a major component of IPM. Cultural control methodologies have been used to manage agricultural pests for centuries because these practices are safe with less expenditure (Al-Zyoud, 2014a,b). However, cultural practices influence both $R$. ferrugineus infestation in the field (Sallam et al., 2012), and the detection efficiency of visual inspection. In this regard, the role of offshoot management, frond pruning, irrigation method, field sanitation, and palm tree density is needed to be adopted to prevent $R$. ferrugineus from spreading from infested palms, reduce the risk of pest attack and facilitate the management of $R$. ferrugineus. Once infested, the trees must be cut into small pieces, buried deeply, or burned. Pruning of palm leaves when they are green must be avoided, this is due to the fact that pruning constitutes a strong attraction for $R$. ferrugineus adults and may facilitate egg laying by females. Pruning should be avoided during the periods of adult activity so it should be carried out during the winter period when the adults are not active and followed directly by insecticidal application on the pruned/cut parts of the tree. Avoiding mechanical damage to trees reduces the pest infestation since $R$. ferrugineus females prefer to lay their eggs in the soft tree tissues (Sallam et al., 2012).

\subsection{Sterile insect technique (SIT)}

Management of $R$. ferrugineus using traditional methods is not effective because detecting early infestation is so difficult. The SIT is highly specific to the target pest. As part of the future IPM of $R$. ferrugineus, trials were set up to assess the possibility of including SIT to target the pest population (Musmeci et al., 2013). To check the efficiency of a SIT strategy, some physiological and behavioral parameters of $R$. ferrugineus reproduction were investigated. By confining females with either irradiated males or wild-type males, the paternity of progeny from multiply mated females was determined. The progeny was almost created by the sperm of the second males, demonstrating that $R$. ferrugineus has a high level of last-male sperm precedence and providing good insights for an area-wide $R$. ferrugineus management utilizing the SIT technique (Musmeci et al., 2018).

\subsection{Gene silencing technology}

The infestation by $R$. ferrugineus is primarily mediated by its ability to locate a host plant by the olfactory detection of aggregation pheromones produced by males (Gunawardena \& Bandarage, 1995). When the OR protein forms a heterodimer with the olfactory co-receptor (Orco), it helps with selectivity and sensitivity. Deleting Orco has been resulted in degrading the OR protein function (Larsson et al., 2004), and thus Orco silencing may inhibit the response of the insect to the pheromones, which could provide a newly advanced tactic for the management of pests. Molecular methods using olfaction interference have the potential to disrupt insect mating and plant locating, and thus 
disturbing insect reproduction. Many authors reported that Orco is a promising target candidate (Franco et al., 2016). Orco disruption by silencing the gene (RNA interference, RNAi) is used widely in protecting crops (Price \& Gatehouse, 2008). The olfactory detection genes were already identified in $R$. ferrugineus (Antony et al., 2016; Soffan et al., 2016). When dsRNA was injected into the dorsal abdomen of $R$. ferrugineus pupae, RferOrco expression was significantly reduced compared to control weevils (not injected). It seems that olfactory disruption applications could successfully lead to the development of a novel pest-management strategy for eradicating R. ferrugineus (Soffan et al., 2016).

\subsection{Quarantine}

Abraham et al. (1998) showed the significance of implementing rigorous quarantine regulations as the main element of $R$. ferrugineus management. Transportation of palm offshoots results in the movement of the pest to new regions. Furthermore, applying strict quarantine regulations to manage the palm nurseries are important to apply IPM of $R$. ferrugineus, prohibit the spread of the pest via plant materials, and maintain control level. Although both domestic and international quarantine regulations do exist to prevent the transportation of infested palm materials, their enforcement is still poorly implemented. Farmer's awareness and cooperation, lack of trained staff, transportation through alternate routes, dearth of certified palm nurseries, and lack of coordination among law enforcement agencies are challenges in the proper implementation of quarantine regulations (Abraham et al., 1998). Dipping offshoots of date palms in insecticides are considered a successful quarantine procedure (Al-Shawaf et al., 2013).

\subsection{Geographical information system (GIS)}

The GIS is the main support tool for decision making in IPM programs, movement control of plant materials, and contingency plans. The wide geographical dispersion and a large amount of data are the keys to the importance of using GIS. A GIS is a system set up to capture, store, handle, analyze, manage and present geographic data. However, the GIS technique was used to check the efficiency of pheromone traps in regions infested by $R$. ferrugineus. A statistical model has already been proposed depending on adult capture information and supports the use of GIS in IPM programs (Massoud et al., 2011, 2012). Systematic GIS-linked data collection is required, for example, employing a large number of maps (traps and adult catches), so that geographical variations in $R$. ferrugineus spread can be tracked and infested palms may be located. High accessibility to mobile-GIS devices enables the development of location-aware surveillance and facilitates the collection of agro-environmental data on time. Regular accumulation of $R$. ferrugineus and distribution and conditions of palm plantation together with treatment history is considered the basis for the decision-making processes.

\section{Conclusions and future perspectives}

The red palm weevil, $R$. ferrugineus has been spreading into new territories and continues to be a destructive pest worldwide; causing economic losses to date palm estimated at billions of dollars. The current review article provides a thorough discussion of the geographical distribution, host plants, economic importance, infestation symptoms, morphology, and biology of R. ferrugineus. Furthermore, this article presents an overview of all control tactics that have been developed to manage $R$. ferrugineus worldwide; including pest surveillance, trapping, chemical control, biological control, bioinsecticides, host plant resistance, cultural control, SIT, gene silencing technology, quarantine, and GIS.

The cryptic lifestyle of $R$. ferrugineus larvae in the trunk exhibits serious detection and management difficulties. Thus, there is an urgent need to develop a fast, accurate, cost-effective, and easily applicable protocol for early detection of $R$. ferrugineus infestation taken into account the trap' type, design, color, placement, density, components, and serviceability.

Many challenges facing date palm farmers to control $R$. ferrugineus including the non-existence of any structured IPM program, poor quarantine protocols, lack of farmer trainings on $R$. ferrugineus issues, and lack of efficient implementation and coordination of all control measures. Thus, it is of vital importance to implement strict quarantine regimes worldwide to limit the spread of $R$. ferrugineus. To sum up, it is recommended to promote awareness among farmers, citizens, municipalities, researchers, non-governmental organizations, and decision makers about the significance of the R. ferrugineus issue. Furthermore, there is a real need to intensify coordination and cooperation among institutions at the global level, use of social media to information transmission, well-known journalists to contribute to raising awareness, networking, capacity building, communication, extension service, and research.

The current state of knowledge indicates that, although no single method perfectly detects $R$. ferrugineus infestation, a combination of detection methods (visual inspection, pheromone traps, thermal, chemical, and acoustic detection) can provide a successful detection of the pest. $R$. ferrugineus control depends mainly on the intensive use of insecticides. However, injection insecticidal treatments lead to the creation of wounds and mechanical weakness that could generate a palm failure risk in the future. Furthermore, there is a lack of protocols for carrying out preventive and curative treatments commonly used to control $R$. ferrugineus, and regular preventive insecticide applications should be avoided to reduce residues in dates.

Although considerable efforts have been made to develop IPM tactics throughout the last 30 years, it is still unable to completely 
manage $R$. ferrugineus in an ecofriendly manner using biological control, plant extracts, SIT, and gene silencing technology. The information available in this review confirms that the entomopathogenic bio-agents (EPF, EPNs, and EPB) are worth to be taken into account for inclusion in $R$. ferrugineus-IPM programs. It appears that future studies are urgently needed on the use of plant extracts, SIT, and gene silencing technology, and the development of transgenic plants to be used as novel effective and environmentally sound strategies to eradicate $R$. ferrugineus. Finally, it is hoped that this review will contribute to the sustainability of date palm production worldwide.

\section{Author Contributions}

All authors (Al-Zyoud F, Shibli R, Ghabeish I) researched in the literature, wrote, reviewed and approved the final version of the manuscript equally.

\section{Funding}

This review paper received no external funding.

\section{Acknowledgments}

None to declare.

\section{Conflicts of Interest}

The authors declare no conflict of interest.

\section{References}

Abbas MST, Hanounik SB,Shahdad AS, Al-Bagham SA (2006) Aggregation pheromone traps, a major component of IPM strategy for the red palm weevil Rhynchophorus ferrugineus (Col., Curculionidae) in date palms. Journal of Pest Science79: 69-73.

Abbas MST, Saleh MME, Akil AM (2001) Laboratory and field evaluation of the pathogenicity of entomopathogenic nematodes to the red palm weevil Rhynchophorus ferrugineus Olivier (Col., Curculionidae). Journal of Pest Science 74: 167-168.

Abd El-Fattaha AY, Abd El-Wahaba AS, Jamalb ZA, El-Helalya AA (2021) Histopathological studies of red palm weevil Rhynchophorus ferrugineus (Olivier) larvae and adults to evaluate certain nano pesticides. Brazilian Journal of Biology 81: 195-201.

Abd-Rabou E, Hussain S, Elsharabasy F, Abouamer WL (2015) Estimation of insecticide residue in date palm fruits after controlling the red palm weevil. International Journal of Food and Nutritional Sciences 4: 27-31.

Abdullah MAR (2009) Biological control of the red palm weevil Rhynchophorus ferrugineus Olivier (Col., Curculionidae) by the parasitoid mite Rhynchopolipus rhynchophori (Ewing) (Acar., Podapolipidae). Journal of the Egyptian Society of Parasitology 39: 679-686.

Abraham VA, Al-Shuaibi MA, Faleiro JR, Abozuhairah RA, Vidyasagar PS (1998) An integrated management approach for red palm weevil Rhynchophorus ferrugineus Olivier, a key pest of date palm in the Middle East. The Journal of Agricultural Science 3: 77-83.

Abuagla AM, Al-Deeb MA (2012) Effect of bait quantity and trap color on the trapping efficacy of the pheromone trap for the red palm weevil Rhynchophorus ferrugineus. Journal of Insect Science12: 120, http://www.insectscience.org/12.120.

Al-Ayedh H (2008) Evaluation of date palm cultivars for rearing the red date palm weevil Rhynchophorus ferrugineus (Col., Curculionidae). Florida Entomologist 91: 353-358.

Al-Dawsari MM (2019) Insecticidal potential of cardamom and clove extracts on adult red palm weevil Rhynchophorus ferrugineus. Saudi Journal of Biological Sciences 26: 897-905.

Al-Deeb M, Muzaffar SB, Abuagla AM, Sharif EM (2012) Distribution and abundance of phoretic mites (Astigmata, Mesostigmata) on Rhynchophorus ferrugineus (Col., Curculionidae). Florida Entomologist 94: 748-755.

Al-Dosary NM, Al-Dobai S, Faleiro JR (2016) Review on the management of red palm weevil Rhynchophorus ferrugineus Olivier in date palm Phoenix dactylifera L. Emirates Journal of Food and Agriculture 28: 34-44.

Al-Jabr AM, Hussain A, Rizwan-Ul-Haq M, Al-Ayedh H (2017) Toxicity of plant secondary metabolites modulating detoxification genes expression for natural red palm weevil pesticide development. Molecules 22: 169. doi: 10.3390/molecules22010169.

Al-Samarrie AI, Akela AA (2011) Distribution of injected pesticides in data palm trees. Agriculture and Biology Journal of North America 12: 1416-1426.

Al-Saoud AH (2013) Effect of ethyl acetate and trap color on weevil captures in red palm weevil Rhynchophorus ferrugineus (Col., Curculionidae) pheromone traps. International Journal of Tropical Insect Science 33: 202-206.

Al-Shawaf AM, Al-Abdan S, Al-Abbad AH, Ben Abdallah A, Faleiro JR (2012) Validating area-wide management of Rhynchophorus ferrugineus (Col., Curculionidae) in date plantation of Al-Hassa. Indian Journal of Plant Protection 40: 255-259.

Al-Shawaf AM, Al-Shagagh AA, Al-Bakshi MM, Al-Saroj SA, Al-Badr SM, Al-Dandan AM, Ben Abdallah A (2010) Toxicity of 
some insecticides against red palm weevil Rhynchophorus ferrugineus (Col., Curculionidae). Indian Journal of Plant Protection 38: 13-16.

Al-Shawaf AM, Al-Shagag AA, Al-Bakshi MM, Al-Saroj SA, AlBather S, Al-Dandan AM, Ben Abdallah A, Faleiro JR (2013) A quarantine protocol against red palm weevil Rhynchophorus ferrugineus Olivier (Col., Curculiondae) in date palm. Journal of Plant Protection Research 53: 409-415.

Al-Zyoud F (2013) Towards integrated pest management of the cereal leafminer Syringopais temperatella Led. (Lep., Scythrididae): status, current and future control options. AmericanEurasian Journal of Agricultural and Environmental Sciences13: 1582-1594.

Al-Zyoud F (2014a) Adoption of integrated pest management among fruit trees' growers in Jordan. Bulletin of Faculty of Agriculture, Cairo University 65: 318-336.

Al-Zyoud F (2014b) Adoption range of integrated pest management techniques by greenhouse vegetable growers in Jordan. Jordan Journal of Agricultural Sciences 10: 504-525.

Al-Zyoud F (2014c) Indiscriminate use and improper application of pesticides by Jordanian vegetable and fruit farmers. Bulletin of Faculty of Agriculture, Cairo University 65: 344-359.

Al-Zyoud F (2015) Investigating barriers to adoption of biological control technology by vegetables and fruit trees' growers in Jordan. Jordan Journal of Agricultural Sciences 11: 1083-1101.

Al-Zyoud F, Hassawi D, Ghabeish I (2015) Oxalic acid as an alienate factor for wheat and barley resistance to cereal leafminer Syringopais temperatella (Lederer, 1855) (Lep., Scythrididae). Shilap Revista de Lepidopterologia 43: 113-123.

Al-Zyoud F, Salameh N, Ghabeish I, Saleh A (2009) Susceptibility of different varieties of wheat and barley to cereal leafminer Syringopais temperatella Led. (Lep., Scythrididae) under laboratory conditions. Journal of Food, Agriculture and Environment 7: 235-238.

Antony B, Soffan A, Jakse J, Abdelazim MM, Aldosari SA, Aldawood AS, Pain A (2016) Identification of the genes involved in odorant reception and detection in the palm weevil Rhynchophorus ferrugineus, an important quarantine pest, by antennal transcriptome analysis. BMC Genome 17: 69-90.

Brand E (1917) Coconut red weevil: some facts and fallacies. Tropical Agriculturist and Magazine of the Ceylon Agricultural Society 49: 22-24.
Chao, CT, Krueger, RR (2007) The date palm (Phoenix dactylifera L.): overview of biology, uses and cultivation. HortScience 42: 1077-1083.

Chihaoui-Meridja S, Garbi A, Abbes K, Chaabane H, Pergola AL, Chermiti B, Suma P (2020) Systematicity, persistence and efficacy of selected insecticides used in endotherapy to control the red palm weevil Rhynchophorus ferrugineus (Olivier, 1790) on Phoenix canariensis. Phytoparasitica 48: 75-85.

Chong JL (2015) Genetic variation and invasion history of the invasive red palm weevil Rhynchophorus ferrugineus Olivier in Terengganu. International Journal of Agriculture, Forestry and Plantation 1: 34-43.

Cito A, Mazza G, Strangi A, Benvenuti C, Barzanti GP, Dreassi E, Turchetti T, Francardi V, Roversi PF (2014) Characterization and comparison of Metarhizium strains isolated from Rhynchophorus ferrugineus. FEMS Microbiology Letters 355: 108-115.

Cohen Y, Alchanatis V, Prigojin A, Levi A, Soroker V, Cohen Y (2012) Use of aerial thermal imaging to estimate water status of palm trees. Precision Agriculture 13: 123-140.

Dembilio O, Jacas JA (2011) Basic bio-ecological parameters of the invasive red palm weevil Rhynchophorus ferrugineus (Col., Curculionidae) in Phoenix canariensis under Mediterranean climate. Bulletin of Entomological Research 101: 153-163.

Dembilio O, Jacas JA (2012) Bio-ecology and integrated management of the red palm weevil Rhynchophorus ferrugineus (Col., Curculionidae) in the region of Valencia, Spain. Hellenic Plant Protection Journal 5: 1-12.

Dembilio O, Jacas JA, Llacer E(2009) Are the palms Washingtonia filifera and Chamaerops humilis suitable hosts for the red palm weevil Rhynchophorus ferrugineus (Col., Curculionidae). Journal of Applied Entomology 133: 565-567.

Dembilio O, Llacer E, Martinez MM, Jacas JA (2010a) Field efficacy of imidacloprid and Steinernema carpocapsae in a chitosan formulation against the red palm weevil Rhynchophorus ferrugineus (Col., Curculionidae) in Phoenix canariensis. Pest Management Science 66: 365-370.

Dembilio O, Quesada-Moraga E, Santiago-Alvarez C, Jacas JA (2010b) Biocontrol potential of an indigenous strain of the entomopathogenic fungus Beauveria bassiana (Ascomycota, Hypocreales) against the red palm weevil Rhynchophorus ferrugineus (Col., Curculionidae). Journal of Invertebrate Pathology 104: 214-221. 
Dembilio O, Riba JM, Gamon M, Jacas JA (2015) Mobility and efficacy of abamectin and imidacloprid against Rhynchophorus ferrugineus in Phoenix canariensis by different application methods. Pest Management Science 71: 1091-1098.

Elawad SA, Mousa SA, Shahbad AS, Alawaash SA, Alamiri AMA(2007)Efficacy of entomopathogenic nematodes against red palm weevil in UAE. Acta Horticulturae736: 415-420.

El-Faki MS, El-Shafie HAF, Al-Hajhoj MBR(2016) Potentials for early detection of red palm weevil (Col., Curculionidae) infested date palm (Arecaceae) using temperature differentials. Canadian Entomologist148: 239-245.

El-Gohary LRA, Abd-El-Hady AA, Abd-El-Hady FM (2015) Efficacy of certain insecticides against red palm weevil, Rhynchophorus ferrugineus (Olivier) under laboratory and field conditions. Journal of Plant Protection and Pathology 6: 55-64.

El-Hadrami A, Al-Khayri JM (2012) Socioeconomic and traditional importance of date palm. Emirates Journal of Food and Agriculture 24: 371-385.

El-Minshawy AM, Hendi RA, Gadelhak GG (2005) Viability of stored polyhedrosis virus of the red palm weevil Rhynchophorus ferrugineus (Olivier) (Col., Curculionidae). FAO/IAEA International Conference on Area-Wide Control of Insect Pests: integrating the Sterile Insect and Related Nuclear and Other Techniques", Vienna, Austria.

El-Saeid MH, Al-Dosari SA (2010) Monitoring of pesticide residues in Riyadh dates by SFE, MSE, SFC and GC techniques. Arab Journal of Chemistry 3: 179-186.

El-Shafie HAF (2012) Review: list of arthropod pests and their natural enemies identified worldwide on date palm Phoenix dactylifera L. Agriculture and Biology Journal of North America 3: 516-524.

El-Shafie HAF, Faleiro JR (2020) Red palm weevil Rhynchophorus ferrugineus (Coleoptera: Curculionidae): global invasion, current management options, challenges and future prospects. In: Invasive species - Introduction pathways, economic impact and possible management options. IntechOpen Limited. London, UK.

El-Shafie HAF, Faleiro JR, Al-Abbad AH, Stoltman L, MafraNeto A (2011) Bait-free attract and kill technology (Hook $\left.{ }^{\mathrm{TM}} \mathrm{RPW}\right)$ to suppress red palm weevil Rhynchophorus ferrugineus (Col., Curculionidae) in date palm. Florida Entomologist 9: 774-778.

Faleiro JR (2006) A review of the issues and management of the red palm weevil Rhynchophorus ferrugineus (Col.,
Rhynchophoridae) in coconut and date palm during the last one hundred years. International Journal of Tropical Insect Science26: 135-154.

Faleiro JR, Al-Dandan AM, Raikar SP, Ben Abdallah A, AlAbdullah I, Gadi AL (2016). Attract and kill technology to control red palm weevil: experiences on date palm in Saudi Arabia and oil palm in India. $2^{\text {nd }}$ Conference Date's Festival in Siwa Oasis, Egypt. ABSTRACT-AttractKill-RPW-Faleiroetal-Siwa-ScientificSeminar Oct2016.pdf.

Faleiro JR, Ben Abdullah A, El-Bellaj M, Al-Ajlan AM, Oihabi A (2012) Threat of red palm weevil Rhynchophorus ferrugineus Olivier to date palm plantations in North Africa. Arab Journal of Plant Protection 30: 274-280.

Faleiro JR, El-Saad MA, Al-Abbad AH (2011)Pheromone trap density to mass trap Rhynchophorus ferrugineus (Col., Curculionidae) in date plantations of Saudi Arabia. International Journal of Tropical Insect Science 31: 75-77.

Faleiro JR, El-Shafie HAF, Al-Ajlan AM, Sallam AA (2014) Screening date palm cultivars for resistance to red palm weevil Rhynchophorus ferrugineus (Col., Curculiondae). Florida Entomologist 97: 1529-1536.

Faleiro JR, Ferry M, Yaseen T, Al-Dobai S (2019)Overview of the gaps, challenges and prospects of red palm weevil management. Arab Journal of Plant Protection 37: 170-177.

FAO (Food and Agriculture Organization of the United Nations) (2017) Current situation of red palm weevil in the NENA region.29-31 March, 2017, Rome, Italy, pp 25.

FAOSTAT (2018) FAO Statistical Database, Food and Agriculture Organization of the United Nation. Retrieve from https://www.fao.org/3/nd415en/nd415en.pdf.

Ferry M (2019) The world situation and the main lessons of 30 years of fight against the red palm weevil. Arab Journal of Plant Protection 37: 109-118.

Ferry M, Gomez S (2012) The control of the red palm weevil. Phytoma 658: 38-41.

Ferry M, Gomez S (2014a) Assessment of risks and potential of injection techniques in integrated programs to eradicate the red palm weevil: review and new perspectives. Fruits 69: 143-157.

Ferry M, Gomez S (2014b) Injection treatments as the main technical component of palm weevil eradication projects. Le Palmier 79: 10-12. 
Ferry M, Gomez S (2015) The last chance strategy to save palm trees. Princeps 1: 125-134.

Francardi, V, Benvenuti C, Barzantiand GP, Roversi PF(2013) Autocontamination trap with entomopathogenic fungi: a possible strategy in the control of Rhynchophorus ferrugineus Olivier (Col., Curculionidae). Redia 96: 57-67.

Franco TA, Oliveira DS, Moreira MF, Leal WS, Melo AC(2016) Silencing the odorant receptor co-receptor RproOrco affects the physiology and behavior of the Chagas disease vector Rhodnius prolixus. Insect Biochemistry and Molecular Biology 69: 82-90.

Giblin-Davis RM, Faleiro JR, Jacas JA, Pena JE, Vidyasagar PS (2013) Biology and management of the red palm weevil Rhynchophorus ferrugineus. In: Pena JE (Ed.). Potential invasive pests of agricultural crop species. CABI Wallingford, UK, Pp 1-34

Golomb O, Alchanatis V, Cohen Y, Levin N,Cohen Y, Soroker $\mathrm{V}$ (2015) Detection of red palm weevil infected trees using thermal imaging. Precision Agriculture 15: 643-650.

Gomez S, Ferry M, Barbado J, Hernandez F, Montero F (2009) Implementation of an integrated control strategy against red palm weevil Rhynchophorus ferrugineus. Phytoma 206: 29-36.

Gopinadhan PB, Mohandas N, Nair KPV (1990) Cytoplasmic polyhedrosis virus infecting red palm weevil of coconut. Current Science 59:577-580.

Gozel U, Gozel C, Yurt C, Inci D (2015) Efficacy of entomopathogenic nematodes on the red palm weevil Rhynchophorus ferrugineus (Olivier, 1790) (Col., Curculionidae) larvae. International Journal of Bioassays 4: 4436-4439.

Guerri-Agullo B, Lopez-Follana R, Asensio L, Barranco P, LopezLlorca L (2011) Use of a solid formulation of Beauveria bassiana for biocontrol of the red palm weevil Rhynchophorus ferrugineus (Col., Dryophoridae) under field conditions in Spain. Florida Entomologist 94: 737-747.

Gunawardena N, Bandarage U (1995) 4-methyl-5-nonanol (ferrugineol) as an aggregation pheromone of the coconut pest Rhynchophorus ferrugineus F. (Col., Curculionidae): synthesis and use in a preliminary field assay. Journal of the National Science Council of Sri Lanka 2: 71-79.

Hajjar MJ, Al-Ajlan AM, Al-Ahmad MH (2015) New approach of Beauveria bassiana to control the red palm weevil (Col., Curculionidae) by trapping technique. Journal of Economic Entomology 108: 425-432.

Hallett RH, Crespi BJ, Borden JH (2004) Synonymy of Rhynchophorus ferrugineus Olivier 1790 and Rhynchophorus vulneratus Panzer 1798 (Col., Curculionidae). Journal of Natural History 38: 2863-2882.

Hallett RH, Gries G, Gries R, Borden JH, Czyzewska E, Oehlschlager AC, Pierce HD, Angerilli NPD, Rauf A (1993) Aggregation pheromones of two Asian palm weevils Rhynchophorus ferrugineus and Rhynchophorus vulneratus. Naturwissenschaft 80: 328-331.

Hallett RH, Oehlschlager AC, Borden JH (1999) Pheromone trapping protocols for the Asian palm weevil Rhynchophorus ferrugineus (Col., Curculionidae). International Journal of Pest Management 45: 231-237.

Hernandez-Marante D, Folk F, Sanchez A, Fernandez-

Escobar R (2003) Control of red palm weevil (Rhynchophorus ferrugineus Olivier) using trunk injections and foliar sprays. Boletin de Sanidad Vegetal Plagas 29: 563-574.

Hetzroni A, Soroker V, Cohen Y (2016) Towards practical acoustic red palm weevil detection. Computers and Electronics in Agriculture 124: 100-106.

Hoddle MS, Hoddle CD, Faleiro JR, El-Shafie HAF, Jeske DR, Sallam AA (2015) How far can the red palm weevil (Col., Curculionidae) fly? Computerized flight mill studies with fieldcaptured weevils. Journal of Economic Entomology 108: 25992609.

Hosseini JF, Dehyouri S, Mirdamadi M (2010) The perception of agricultural researchers about the role of nanotechnology in achieving food security. African Journal of Biotechnology 9: 61526157.

Hussain A, Rizwan-Ul-Haq M, Al-Ayedh H, Ahmed S, Al-Jabr AM (2015) Effect of Beauveria bassiana infection on the feeding performance and antioxidant defence of red palm weevil Rhynchophorus ferrugineus. BioControl 60: 849-859.

Hussain A, Rizwan-Ul-Haq M, Al-Jabr AM, Al-Ayedh HY (2013) Managing invasive populations of red palm weevil: a worldwide perspective. Journal of Food, Agriculture and Environment 11: 456-463.

Hussain A, Rizwan-Ul-Haq M, Al-Jabr AM, Al-Ayedh HY (2019)Lethality of sesquiterpenes reprogramming red palm weevil detoxification, mechanism for natural novel biopesticide development. Molecules 24: 1648-1660.

Jalinas J, Guerri-Agullo B, Mankin RW, Lopez-Follana R, LopezLlorca LV(2015) Acoustic assessment of Beauveria bassiana (Hypocreales: Clavicipitaceae) effects on Rhynchophorus 
ferrugineus (Col., Dryophthoridae) larval activity and mortality. Journal of Economic Entomology 108: 444-453.

Jonoobi M, Shafie M, Shirmohammadli Y, Ashori A, Hosseinabadi Z, Mekonnen T (2019) A review on date palm tree: properties, characterization and its potential applications. Journal of Renewable Materials 11: 1055-1075.

Ju RT, Wang F, Wan FH, Li B(2011) Effect of host plants on development and reproduction of Rhynchophorus ferrugineus Olivier (Col., Curculionidae). Journal of Pest Science 84: 33-39.

Kaakeh W (2006) Toxicity of imidacloprid to developmental stages of Rhynchophorus ferrugineus (Col., Curculionidae): laboratory and field tests. Crop Protection 25: 432-439.

Kanzaki N, Abe F, Giblin-Davis RM, Kiontke K, Fitch DH, Hata K, Sone K (2008) Teratorhabditis synpapillata Sudhaus 1985 (Rhabditida: Rhabditidae) is an associate of the red palm weevil Rhynchophorus ferrugineus (Col., Curculionidae). Nematology 10: 207-218.

Kehat M (1999)Threat to date palms in Israel, Jordan and the Palestinian Authority by the red palm weevil Rhynchophorus ferrugineus. Phytoparasitology 27: 241-242.

Khalifa O, El-Assal AH, El-Ezaby FAA, Murse MA, Al-Nuaimi SM, Al-Zehli NS (2007)Database for infestation of date palm by red palm weevil Rhynchophorus ferrugineus in UAE and Oman. $2^{\text {nd }}$ International Conference on Date Palm, Al-Ain, UAE, March 25-27, Pp 186-210.

Kogan M (1998) Integrated pest management: historical perspectives and contemporary developments. Annual Review of Entomology 43: 243-270.

Kontodimas DC, Milonas PG, VassiliouVV, Thymakis NI, Economou D(2006) The occurrence of Rhynchophorus ferrugineus in Greece and Cyprus and the risk against the native Greek palm tree Phoenix theophrasti. Entomologia Hellenica16: 11-15.

Kranthi KR, Jadhav DR, Wanjar RR, Shaker AS, Russell D(2001) Carbamate and organophosphate resistance in cotton upsets in India, 1995-1999. Bulletin of Entomological Research 91: 37-46.

Kring JJ (1998) Predaceous Coccinellidae in biological control. Annual Review of Entomology 43: 295-321.

Kurdi H, Al-Aldawsari A, Al-Turaiki I, Aldawood AS (2021) Early detection of red palm weevil, Rhynchophorus ferrugineus (Olivier), infestation using data mining. Plants 10: 95, https://doi.org/10.3390/plants10010095.
Larsson M, Domingos A, Jones W, Chiappe M, Amrein H, Vosshall LB(2004) Or83b encodes a broadly expressed odorant receptor essential for Drosophila olfaction. Neuron 43: 703-714.

Lefroy HM (1906)The more important insects injurious to Indian agriculture.Government Press, Calcutta, India.

Littardi C, Cangelosi B, Lucido P, Sacco M, Pozzi L(2013)Propagation of Rhynchophorus ferrugineus in Italy and contribution to the early detection of infestations by the use of electronic nose. Acta Horticulturae 994: 53-58.

Llacer E, Santiago-Alvarez C, Jacas JA (2013)Could sterile males be used to vector a microbiological control agent? The case of Rhynchophorus ferrugineus and Beauveria bassiana. Bulletin of Entomological Research 103: 241-250.

Mahmoud MMA, Ismail IM, Amin MK, Fayedi AH, Mostafa SA (2011)Isolation and identification of novel local isolates of Bacillus thuringiensis active against red palm weevil. Egyptian Journal of Genetics and Cytology 40: 337-350.

Mahmud AI, Farminhao J, Viez ERA (2015) Red palm weevil Rhynchophorus ferrugineus Olivier, 1790: threat of palms. Journal of Biological Sciences 15: 56-67.

Malik MA, Ahmad SJN,Ahmad JN, Abbasi A, Sufyan M, Arif MJ(2019) Efficacy of Bacillus thuringiensis and Beauveria bassiana against red palm weevil Rhynchophorus ferrugineus Olivier (Col., Curculionidae). African Entomology 27: 386-394.

Manachini B, Bue P, Peri E, Colazza S (2009) Potential effects of Bacillus thuringiensis against adults and older larvae of Rhynchophorus ferrugineus. IOBC/WPRS Bulletin 45: 239-242.

Mankin RW, Al-Ayedh HY, Aldryhim Y, Rohde B (2016)Acoustic detection of Rhynchophorus ferrugineus (Col., Dryophthoridae) and Oryctes elegans (Col., Scarabaeidae) in Phoenix dactylifera (Arecales, Arecacae) trees and offshoots in Saudi Arabian orchards. Journal of Economic Entomology 109: 622-628.

Mankin RW, Hagstrum DW, Smith MT, Roda AL, Kairo MTK (2011) Perspective and promise: a century of insect acoustic detection and monitoring. American Entomologist 57: 30-44.

Mankin RW, Mizrach A, Hetzroni A, Levsky S, Nakache Y, Soroker V (2008) Temporal and spectral features of sounds of wood-boring beetle larvae: identifiable patterns of activity enable improved discrimination from background noise. Florida Entomologist 91: 241-248.

Manzoor M, Ahmad JN, Sharif MZ, Majeed D, Kiran H, Jafir M, Ali H(2017)Comparative effectiveness of entomopathogenic 
nematodes against red palm weevil Rhynchophorus ferrugineus in Pakistan. Journal of Entomology and Zoology Studies 5: 756-760.

Marsh TL, Gallardo K (2009) Adopting biological control for ornamental crops in greenhouses. CAB Reviews 4: 1-9.

Martin B (2015) A relative analysis on sound of red palm weevil based on field and lab recordings. International Journal of Applied Engineering Research 10: 5261-5268.

Massoud MA, Faleiro JR, El-Saad MA, Sultan E (2011) Geographic information system used for assessing the red palm weevil Rhynchophorus ferrugineus Olivier in date palm oasis of Al-Hassa, Saudi Arabia. Journal of Plant Protection Research 51: 234-239.

Massoud MA, Sallam AA, Faleiro JR, Al-Abdan S(2012) Geographic information system-based study to ascertain the spatial and temporal spread of red palm weevil Rhynchophorus ferrugineus (Col., Curculionidae) in date plantations. International Journal of Tropical Insect Science 32: 108-115.

Mastore M, Arizza V, Manachini B, Brivio MF (2015) Modulation of immune responses of Rhynchophorus ferrugineus (Insecta: Col.) induced by the entomopathogenic nematode Steinernema carpocapsae (Nematoda: Rhabditida). Insect Science 22: 748-760.

Mazza G, Francardi V, Simoni S, Benvenuti C, Cervo R, Faleiro JR, Llacer E, Longo S, Nannelli R, Tarasco E, Roversi PF (2014) An overview on the natural enemies of Rhynchophorus palm weevils with focus on Rhynchophorus ferrugineus. Biological Control 77: 83-92.

Mohammed MEA, El-Shafie HAF, Alhajhoj MR (2020) Invasive species - Introduction pathways, economic impact and possible management options. Chapter: Recent trends in the early detection of the invasive red palm weevil, Rhynchophorus ferrugineus (Olivier). IntechOpen, London, United Kingdom.

Morohashi M, Nagasawa S, Enya N, Suzuki K, Kose T, Kawata K (2012)Behavior of bromobutide in paddy water and soil after application. Bulletin of Environmental Contamination and Toxicology 88: 521-525.

Musmeci S, Belvedere S, Sasso R, Arnone S, Cristofaro M, Nobili P, Marca A, de Biase A (2018) Last-male sperm precedence in Rhynchophorus ferrugineus Olivier: observations in laboratory mating experiments with irradiated males. Bulletin of Entomological Research 108: 93-100.

Musmeci S, Cristarom M, Sasso R, Baccaro S, Pasquali A, Catarci S (2013) Control of red palm weevil by sterile insect technique
(SIT): feasible or impossible? Atti Della Accademia Nazionale Italiana di Entomologia 111: 239-246.

Naranjo SE, Ellsworth OC (2009) Fifty years of the integrated control concept: moving the model and implementation forward in Arizona. Pest Management Science 65: 1267-1286.

Nassar MM, Abdullah MA (2001) Evaluation of Azadirachtin for control of the red palm weevil Rhynchophorus ferrugineus Olivier (Col., Curculionidae). Journal of the Egyptian-German Society of Zoology and Entomology 36: 163-173.

Nassar MM, Abdullah MA (2005) Assessment of Boxus chinensis oil and Precocene II for the control of the red palm weevil Rhynchophorus ferrugineus Olivier (Col., Curculionidae) and the palm beetle Pseudophilus testaceous (Gahan) (Col., Cerambycidae). Journal of Entomology 2: 1-8.

Oehlschlager AC (2016) Palm weevils' pheromones: discovery and use.Journal of Chemical Ecology 42: 617-630.

Ofuoku AU, Egho EO, Enujeke EC (2009) Integrated pest management adoption among farmers in central agro-ecological zone of Delta State, Nigeria. Advances in Biological Research 3: 29-33.

Pereira V (2017) Most destructive pest 'red palm weevil' strikes coconut palms in Mangaluru.Team Mangalorean, retrieve from https://www.mangalorean.com/most-destructive-pest-re d-pa lmweevil-strikes-coconut-palms-in-mangaluru/.

Potamitis I, Ganchev T, Kontodimas D (2009)On automatic bioacoustic detection of pests: the cases of Rhynchophorus ferrugineus and Sitophilus oryzae. Journal of Economic Entomology 102: 1681-1690.

Potamitis I, Rigakis I (2015) Smart traps for automatic remote monitoring of Rhynchophorus ferrugineus (Col., Curculionidae). PeerJournal PrePrints 3: doi.org/10.7287/peerj.Prepr ints.1337v1.

Price DR, Gatehouse JA (2008) RNAi-mediated crop protection against insects. Trends in Biotechnology 26: 393-400.

Psirofonia P, Samaritakis V, Eliopoulos P, Potamitis I (2017) Use of unmanned aerial vehicles for agricultural applications with emphasis on crop protection: three novel case-studies. International Journal of Agricultural Technology 5: 30-39.

$\mathrm{Pu}$ YC, Hou YM (2016) Isolation and identification of bacterial strains with insecticidal activities from Rhynchophorus ferrugineus Olivier (Col., Curculionidae). Journal of Applied Entomology 140: 617-626. 
Pu YC, Ma TL, Hou YM, Sun M (2017) An entomopathogenic bacterium strain Bacillus thuringiensis as a biological control agent against the red palm weevil Rhynchophorus ferrugineus (Col., Curculionidae). Pest Management Science 73: 1494-1502.

Rach MM,Gomis HM, Granado OL,Malumbres MP, Campoy AM, Martin JJ (2013) On the design of a bioacoustic sensor for the early detection of the red palm weevil. Sensors 13: 1706-1729.

Ragaei M, Gesraha MA,Mohamed H, El-Shishtawi R (2009) Symbiotic flagellated protozoa isolated from red palm weevil Rhynchophorus ferrugineus Olivier (Col., Curculionidae). Australian Journal of Basic and Applied Sciences 3: 604-606.

Sabit H, Abdel-Ghany S, Al-Dhafar Z, Said O, Al-Saeed J, Alfehaid Y, Osman M (2021) Molecular characterization and phylogenetic analysis of Rhynchophorus ferrugineus Olivier in Eastern Province, Saudi Arabia. Saudi Journal of Biological Sciences 28: 5621-5630.

Salama HS (2007) Potential of certain natural extracts for the control of the red palm weevil Rhynchophorus ferrugineus Olivier. Archives of Phytopathology and Plant Protection 40: 233-236.

Salama HS, Abdel-Razek AS (2002) Development of the red palm weevil Rhynchophorus ferrugineus Olivier (Col., Curculionidae) on natural and synthetic diets. Anzeiger fur Scha Dlingskunde 75: 137-139.

Salama HS, Foda MS, El-Bendary MA, Abdel-Razek AS (2004) Infection of red palm weevil Rhynchophorus ferrugineus by sporeforming bacilli indigenous to its natural habitat in Egypt. Journal of Pest Science 77: 27-31.

Sallam AA, El-Shafie HAF, Al-Abdan S(2012) Influence of farming practices on infestation by red palm weevil Rhynchophorus ferrugineus Olivier in date palm: a case study. International Research Journal of Agricultural Science and Soil Science2: 370-376.

Santhi VS, Salame L, Nakache Y, Koltai H, Soroker V,Glazer I(2015) Attraction of entomopathogenic nematodes Steinernema carpocapsae and Heterorhabditis bacteriophora to the red palm weevil Rhynchophorus ferrugineus. Biological Control 83: 75-81.

Sarwar M (2016) Biological control of red palm weevil Rhynchophorus ferrugineus (Col., Curculionidae) by the natural enemies. International Journal for Research in Biology and Pharmacy 2: 22-35.

Sarwar M, Ashfaq M, Ahmed A, Randhawa MAM (2013) Assessing the potential of assorted plant powders on survival of Caloglyphus grain mite (Acari, Acaridae) in wheat grain.
International Journal of Agricultural Science and Bioresource Engineering Research 2: 1-6.

Sewify GH, Belal MH, Al-Awash SA (2009)Use of the entomopathogenic fungus Beauveria bassiana for the biological control of the red palm weevil Rhynchophorus ferrugineus Olivier. Egyptian Journal of Biological Pest Control 19: 157-163.

Shannag HK, Capinera JL, Freihat NM (2015) Effects of neembased insecticides on consumption and utilization of food in larvae of Spodoptera eridania (Lep., Noctuidae). Journal of Insect Science15: 152-159.

Shojaei SH, Hosseini SJ, Mirdamadi M, Zamanizadeh HR(2013)Investigating barriers to adoption of integrated pest management technologies in Iran. Annals of Biological Research 4: $39-42$.

Smith CM, Clement SL (2012) Molecular bases of plant resistance to arthropods. Annual Review of Entomology 57: 309-328.

Soffan A, Antony B, Abdelazim M, Shukla P, Witjaksono W, Aldosari SA, Aldawood AS (2016) Silencing the olfactory coreceptor RferOrco reduces the response to pheromones in the red palm weevil Rhynchophorus ferrugineus. PLos One 11: doi: 10.1371/ journal.pone.016 2203.

Soroker V, Blumberg DA, Haberman M, Hamburger-Rishard S, Reneh S, Talebaev L, Anshelevich L, Harari AR (2005) Current status of red palm weevil infestation in date palm plantations in Israel. Phytoparasitology 33: 97-106.

Soroker V, Goldenberg I, Kniazer A, Davidovich M, Goldshtein E (2017) Red palm weevil trapping: can we improve the system. Alon Hanotea 71: 33-37.

Soroker V, Harari A, Faleiro JR (2015)The role of semiochemicals in date pest management. In: Wakil W, Faleiro JR, Miller T (Ed.). Sustainable pest management in date palm: current status and emerging challenges. Springer International Publication, Switz., Pp 445 .

Suma P, Pergola A, Longoand S, Soroker V (2014)The use of the sniffing dogs for the detection of Rhynchophorus ferrugineus (Col., Dryophthoridae). Phytoparasitology 42: 269-274.

Tenghberg M (2012) Beginning and early history of date palm garden cultivation in the Middle East. Journal of Arid Environment 86: $139-147$.

Triggiani O, Tarasco E (2011) Evaluation of the effects of autochthonous and commercial isolates of Steinernematidae and Heterorhabditidae on Rhynchophorus ferrugineus. Bulletin of Insectology 64: 175-180. 
Uwagboe EO, Akinbile LA, Oduwole OO (2012) Socio-economic factors and integrated pest management utilization among cocoa farmers in Edo State. Academic Journal of Plant Sciences 5: 7-11.

Vacas S, Abad-Paya M, Primo J, Navarro-Llopis V (2014) Identification of pheromone synergists for Rhynchophorus ferrugineus trapping systems from Phoenix canariensis palm volatiles. Journal of Agricultural and Food Chemistry 62: 60536064.

Vacas S, Melita O, Michaelakis A, Milonas P, Minuz R, Riolo P, Abbas MK, Bue P, Colazza S, Peri E, Soroker V, Livne Y, Primo J, Navarro-Llopis V (2017) Lures for red palm weevil trapping systems: aggregation pheromone and synthetic kairomone. Pest Management Science 73: 223-231.

Vacas S, Primo J, Navarro-Llopis V (2013) Advances in the use of trapping systems for Rhynchophorus ferrugineus (Col., Curculionidae): traps and attractants. Journal of Economic Entomology 106: 1739-1746.

Vidyasagar PS, Al-Saihati AA, Al-Mohanna OE, Subbei AI, Abdul-Mohsin AM (2000) Management of red palm weevil
Rhynchophorus ferrugineus Olivier, a serious pest of date palm in Al-Qatif, KSA. Journal of Plantation Crops 8: 35-43.

Wahizatul AA, Chik Z, Abdul Rahman AR, Nurul-Izzah AG (2013)A new invasive coconut pest in Malaysia: the red palm weevil Rhynchophorus ferrugineus (Curculionidae). Planter 89: 97-110.

Wakil W, Yasin M, Qayyum M, Ghazanfar M, Al-Sadi A, Bedford G, Kwon Y (2018) Resistance to commonly used insecticides and phosphine fumigant in red palm weevil, Rhynchophorus ferrugineus Olivier in Pakistan. Plos One 13(7): e0192628.

Wakil W, Yasin M, Shapiro-Ilan D (2017) Effects of single and combined applications of entomopathogenic fungi and nematodes against Rhynchophorus ferrugineus Olivier. Science Reports 7: 5971 doi:10.1038/s41598-017-05615-3.

Zohary D, Hopf M (2000) Domestication of palms in the old world: the origin and spread of cultivated plants in West Asia, Europe and the Nile Valley. $3^{\text {rd }}$ Edn., Oxford University Press, Oxford, UK, pp 316. 